\title{
Insulin-like growth factor-I and wound healing, a potential answer to non-healing wounds: A systematic review of the literature and future perspectives
}

\author{
ZOE GAROUFALIA $^{1 *}$, ARGYRO PAPADOPETRAKI ${ }^{2}$, ELLI KARATZA $^{1 *}$, DIMITRIOS VARDAKOSTAS $^{1 *}$, \\ ANASTASSIOS PHILIPPOU ${ }^{2}$, GREGORY KOURAKLIS ${ }^{1}$ and DIMITRIOS MANTAS ${ }^{1}$ \\ ${ }^{1}$ Second Department of Propaedeutic Surgery, Laiko General Hospital; \\ ${ }^{2}$ Department of Physiology, Medical School, National and Kapodistrian University of Athens, Athens 11527, Greece
}

Received February 5, 2021; Accepted May 17, 2021

DOI: $10.3892 /$ br.2021.1442

\begin{abstract}
The induction of wound healing by insulin-like growth factor-I (IGF-I) has been demonstrated in several animal studies; however, there are disproportionately fewer studies assessing its value in humans. The aim of the present review is to provide a comprehensive summary of all the available evidence pertaining to the effects of IGF-I administration on the process of wound anaplasias, both in human tissues in vivo and in cells in vitro. A systematic search of Medline, Scopus and Google Scholar was performed for relevant studies published until May 2020. Overall, 11 studies were included. Of these, 2 studies were conducted in human subjects, whereas the rest of them were performed using in vitro models of human cell lines. All studies demonstrated a positive association between IGF-I and wound anaplasias; IGF-I promoted the migration of keratinocytes, thus playing an important role in wound epithelialization as well as enabling wound bed contraction, and it also stimulated hyaluronan synthesis. The wound healing-promoting effect of IGF-I may be a great asset in dealing with the healing of challenging wounds; thus, this type of treatment could be extremely useful in addressing patients with large burn wounds, chronic diabetic ulcers and patients with impaired wound healing. Nevertheless, the route of recombinant IGF-I administration, the recommended dosage, as well as the indications for clinical use of this growth factor remain to be determined and thus, additional clinical trials are required, with a focus on the medical use of recombinant IGF-I in wound anaplasias.
\end{abstract}

Correspondence to: Dr Zoe Garoufalia, Second Department of Propaedeutic Surgery, Laiko General Hospital, 17 Agiou Thoma Street, Athens 11527, Greece

E-mail: zoegaroufalia@gmail.com

${ }^{*}$ Contributed equally

Key words: anaplasias, chronic ulcers, IGF-I, tissue regeneration

\section{Introduction}

Wound anaplasias is a dynamic and particularly complex process that involves several cell types (such as keratinocytes and fibroblasts) as well as fundamental cellular processes, including proliferation, differentiation and migration (1). The biological responses of these cells are initiated and mediated primarily by growth factors, acting solely or in combination with other factors, in a paracrine or autocrine manner (2-4).

In particular, wound healing involves both proliferation and migration of keratinocytes from the wound edges, under the influence of several growth factors (5). The insulin-like growth factor-I (IGF-I), also termed somatomedin C, is a hormone similar to insulin in terms of its molecular structure, which plays an important role during puberty and displays several anabolic effects in humans (5). Approximately $98 \%$ of IGF-I is bound to one of six binding proteins. IGFBP-3 accounts for $80 \%$ of all IGF binding (6). IGF-I promotes its effect by binding to specific receptors on the cell surface (7). There is a growing body of evidence showing that IGF-I serves an important role in the regeneration of several different tissues following injury (8-12). Interestingly, despite this growing body of literature showing the wound healing effects of IGF-I in animals (13-16), there are only a few studies investigating its effects in humans.

In this context, a systematic search of the literature was performed to provide a summary of all the available evidence regarding the effects of IGF-I administration on wound healing in humans, and to outline the perspectives for future studies and medical applications. The present review is the first systematic review summarizing the role of IGF-I in wound healing in humans.

\section{Materials and methods}

A systematic search of MEDLINE, Scopus and Google Scholar were performed using the terms 'IGF-I', 'insulin-like growth factor I' and 'wound', 'healing' and 'regeneration' combined with the Boolean operators AND/OR, to identify studies performed in humans on the effects of IGF-I in the process of wound healing published until May 2020. A priori 
selected exclusion criteria were: i) reviews, editorials and clinical vignettes; ii) animal studies; iii) studies without explicitly reported experimental details; iv) studies were the full-text was unavailable; and v) studies published in any language other than English.

Following removal of duplicate studies, the abstract list generated by the above search was independently screened by two authors for identification of potentially relevant studies. After excluding papers of obvious irrelevance, full-text evaluation of all remaining studies was performed for completeness and eligibility of reported data, according to the aforementioned inclusion/exclusion criteria. Any ensuing disagreements were resolved by a third reviewer. Reference lists of all relevant studies were further manually checked. The present review was performed according to the PRISMA guidelines (17) (Fig. S1).

Data of interest that were recorded, including the type of study and year of publication, the external administration of IGF-I or measurements of endogenous IGF-I production, the human tissue or cell type investigated, whether the study was performed in vivo or in vitro, as well as the experimental outcomes. After thorough full-text evaluation of the included studies, data of interest were inserted into Microsoft Excel 2014 (Microsoft Corporation) and were subsequently crosschecked by two of the authors for discrepancies.

\section{Results}

The initial search of the aforementioned databases yielded 765 studies. After duplicate removal, 735 studies were screened and 686 were excluded. A total of 49 full text articles were assessed for eligibility. Finally, 11 studies were included in this review, with the year of their publication ranging from 1992-2010.

Of these 11 studies, 2 were performed in vivo and the other 9 were performed in vitro using human cell cultures primarily obtained from infant foreskin. Specifically, the study by Vogt et al (18) was performed on split-thickness skin wounds of patients that had undergone reconstructive plastic surgery, whereas the study by Wicke et al (19) was performed on surgical wounds of orthopedic patients. Endogenous levels of IGF-I were measured during wound healing in the in vivo studies, whilst all cell culture experiments involved exogenous administration of IGF-I. Several other growth factors were studied in parallel with IGF-I, utilizing either PCR or immunoassay studies.

The majority of studies revealed that IGF-I is an important mitogen involved during the process of wound healing. Specifically, both in vitro $(13,20-22)$ and in vivo (18) studies showed that IGF-I is an important stimulant for the migration of keratinocytes, thus playing a central role in wound epithelialization. Lee et al (23) demonstrated that IGF-I assisted in wound bed contraction, minimizing the gap between the edges of the wound. In particular, the combination of IGF-I and IGFBP-1 promoted wound bed contraction, which is a critical step of wound healing (23). Additionally, Kuroda et al demonstrated that IGF-1 results in the stimulation of hyaluronan synthesis in vitro (24). Interestingly, the aged patients appeared to exhibit lower plasma as well as wound levels of IGF-I, which resulted in delayed wound healing (19). Hyde et al (25) in 2004 demonstrated that IGF-I combined with extracellular matrix protein vitronectin resulted in significantly enhanced protein synthesis and cell migration in the wound area (25). Moreover, Lee et al (26) demonstrated the role of IGF-1 in fibroblast proliferation and keratinocyte migration. Table I summarizes the outcomes of the reviewed studies.

\section{Discussion}

Wound healing is a complex process that occurs in several phases and involves several factors. IGF-I is a hormone that plays an important role during growth and development, and is expressed in several tissues in humans where its exerts several anabolic effects $(27,28)$. The liver is the primary source of generation of circulating IGF-I $(27,28)$, although local secretion of IGF-I has been observed in multiple tissues (29). Beyond its central role as a promoter of growth, IGF-I is involved in the normal function of several organs, such as the kidneys, brain, skeletal muscle and bone, amongst others (30-33). Furthermore, IGF-I possesses a crucial role in wound healing via multiple mechanisms; it acts as a chemotactic agent for endothelial cells, stimulates the proliferation and migration of keratinocytes and fibroblasts, and increases the wound strength (34).

Several animal studies have been conducted to assess the role of IGF-I in the process of wound anaplasias, using both local as well as systemic administration. Lynch et al (3) demonstrated a $132 \%$ increase in the dermal thickness and a $300 \%$ increase in the number of connective tissue cells within the wound site as well as in the collagen content and maturity, following the application of recombinant IGF-I and platelet-derived growth factor-2 in partial thickness wounds, which were surgically induced in the back and thoracic areas of young white Yorkshire pigs. In addition, Skottner et al (35) studied the anabolic actions of IGF-I following systemic and local administration in mutant dwarf rats. The results of their study indicated that local administration of IGF-I had a significant positive effect on wound regeneration. Moreover, a placebo-controlled trial demonstrated that IGF-I depletion in hypophysectomized rats decreased wound protein levels and hydroxyproline content by $50 \%$, and that IGF-I infusion returned the levels of these variables to normal (36).

Given the above findings in animal models, further studies were performed regarding the optimum means of IGF-I delivery in the wound micro-environment. Jeschke et al (37) concluded that liposomal IGF-I gene transfer can accelerate wound anaplasias. Moreover, another study examining the role of systemic administration of IGF-I in rats concluded that IGF-I improved the healing process in collagenous tissue (38).

Several other studies have shown that IGF-I contributes to the repair of a variety of tissues; Lu et al (39) demonstrated the ability of IGF-I to promote repair of skeletal muscle tissue, and Kluge et al (40) in myocardial tissue. Moreover, the significance of IGF-I in airway remodeling has been also found in patients with inflammatory bowel disorder (41), and IGF-I was shown to attenuate TNF- $\alpha$ and IL-1 $\beta$ production in rat burn wounds (42).

The present study has some limitations. There were significant differences between the sample sizes and methodology of the reviewed studies. The evidence provided in the present review is limited by the heterogeneity of the included studies. Additionally, the vast majority of IGF-I studies have 
Table I. Summary of the results in the reviewed studies.

\begin{tabular}{|c|c|c|c|c|c|c|}
\hline $\begin{array}{l}\text { First author, } \\
\text { year }\end{array}$ & $\begin{array}{l}\text { In vitrol } \\
\text { in vivo }\end{array}$ & Method & $\begin{array}{l}\text { Tissue/cell } \\
\text { type (origin) }\end{array}$ & $\begin{array}{c}\text { Growth } \\
\text { factors assessed }\end{array}$ & Results & Refs. \\
\hline $\begin{array}{l}\text { Barreca et al, } \\
1992\end{array}$ & In vitro & Northern blot & $\begin{array}{l}\text { Cell culture } \\
\text { (human } \\
\text { keratinocytes- } \\
\text { skin biopsy) }\end{array}$ & IGF-I, IGF-II & $\begin{array}{l}\text { Human fibroblasts synthesize IGF } \\
\text { peptides, whereas keratinocytes do not. } \\
\text { Fibroblast-derived IGFs stimulate } \\
\text { keratinocyte growth in a paracrine fashion, } \\
\text { highlighting their potential role in the } \\
\text { regulation of keratinocyte proliferation, } \\
\text { in skin growth and in wound healing. }\end{array}$ & (44) \\
\hline $\begin{array}{l}\text { Tsuboi et al, } \\
1992\end{array}$ & In vitro & $\begin{array}{l}\text { Sato and } \\
\text { Rifkin method }\end{array}$ & $\begin{array}{l}\text { Cell culture } \\
\text { (human } \\
\text { keratinocytes- } \\
\text { infant foreskins) }\end{array}$ & $\begin{array}{l}\text { IGF-I, TGF- } \alpha \text {, } \\
\text { aFGF, bFGF, } \\
\text { KGF }\end{array}$ & $\begin{array}{l}\text { TGF- } \alpha, \text { aFGF, bFGF, KGF and IGF-I } \\
\text { stimulate the migration of keratinocytes, } \\
\text { whereas as TGF- } \beta 2 \text { suppresses it. }\end{array}$ & (20) \\
\hline $\begin{array}{l}\text { Kratz et al, } \\
1994\end{array}$ & In vitro & $\begin{array}{l}\text { Estimation of } \\
\text { re-epithelializatio }\end{array}$ & $\begin{array}{l}\text { Sterile human } \\
\text { akin }\end{array}$ & $\begin{array}{l}\text { IGF-I, IGF-II, } \\
\text { IGFBP-1 } \\
\text { (mastectomy } \\
\text { specimens) }\end{array}$ & $\begin{array}{l}\text { IGF-1 stimulates efficient } \\
\text { re-epithelialization of } \\
\text { the wounds both alone and in the } \\
\text { presence of recombinant IGFBP-1. }\end{array}$ & (21) \\
\hline $\begin{array}{l}\text { Bhora et al, } \\
1995\end{array}$ & In vitro & $\begin{array}{l}\text { Immuno- } \\
\text { histochemistry }\end{array}$ & $\begin{array}{l}\text { Full thickness skin } \\
\text { (amputated lower } \\
\text { extremities) }\end{array}$ & IGF-I, FGF & Important mitogens & (13) \\
\hline $\begin{array}{l}\text { Lee et al, } \\
1996\end{array}$ & In vitro & $\begin{array}{l}\text { Estimation of } \\
\text { gel contraction }\end{array}$ & $\begin{array}{l}\text { Cell culture } \\
\text { (human keratinocytes- } \\
\text { infant foreskins) }\end{array}$ & $\begin{array}{l}\text { IGF-I, } \\
\text { IGFBP-1 }\end{array}$ & $\begin{array}{l}\text { The combination of IGF-I and } \\
\text { IGFBP-1 promotes the contraction of } \\
\text { fibroblast-embedded collagen gel }\end{array}$ & (23) \\
\hline $\begin{array}{l}\text { Vogt et al, } \\
1998\end{array}$ & In vivo & ELISA & $\begin{array}{l}\text { Split-thickness skin } \\
\text { wounds (reconstructive } \\
\text { surgery) }\end{array}$ & $\begin{array}{l}\text { IGF-I, } \\
\text { TGF- } \beta 2\end{array}$ & $\begin{array}{l}\text { Stimulation of } \\
\text { epithelialization during the first day }\end{array}$ & (18) \\
\hline $\begin{array}{l}\text { Kuroda et al, } \\
2001\end{array}$ & In vitro & PCR & $\begin{array}{l}\text { Cell culture } \\
\text { (normal adult skin) }\end{array}$ & IGF-I, FGF & $\begin{array}{l}\text { Stimulation of hyaluronansynthesis, } \\
\text { with important implications } \\
\text { for tissue remodeling, such as } \\
\text { in development and wound healing. }\end{array}$ & (24) \\
\hline $\begin{array}{l}\text { Wicke et al, } \\
2002\end{array}$ & In vivo & ELISA & $\begin{array}{l}\text { Surgical trauma } \\
\text { (orthopedic } \\
\text { surgery) }\end{array}$ & $\begin{array}{l}\text { IGF-I, IGF-II, } \\
\text { IGFBP-3 }\end{array}$ & $\begin{array}{l}\text { Aged patients had lower plasma levels } \\
\text { and correspondingly lower wound } \\
\text { localized levels of IGF-I, } \\
\text { IGFBP-3 on all } 4 \text { postoperative days. } \\
\text { Plasma and wound fluid levels were } \\
\text { reduced by } 25-70 \% \text { in the aged patients }\end{array}$ & (19) \\
\hline $\begin{array}{l}\text { Haase et al, } \\
2003\end{array}$ & In vitro & PCR & $\begin{array}{l}\text { Cell culture } \\
\text { (human } \\
\text { keratinocytes- } \\
\text { infant foreskins) }\end{array}$ & IGF-I & $\begin{array}{l}\text { IGF-I can influence different } \\
\text { components of the keratinocyte } \\
\text { migration machinery that determines } \\
\text { the speed of wound epithelialization. }\end{array}$ & (22) \\
\hline $\begin{array}{l}\text { Hyde et al, } \\
2004\end{array}$ & In vitro & PCR & $\begin{array}{l}\text { Cell culture } \\
\text { (HaCAT-human } \\
\text { keratinocytes) }\end{array}$ & $\begin{array}{l}\text { IGF-II:VN } \\
\text { and IGF-I: } \\
\text { IGFBP-5:VN }\end{array}$ & $\begin{array}{l}\text { Functional assays demonstrated that } \\
\text { both the IGF-II:VN and } \\
\text { IGF-I:IGFBP-5:VN complexes resulted } \\
\text { in significantly enhanced protein } \\
\text { synthesis and cell migration through Transwell } \\
\text { pores in skin keratinocytes (HaCAT). }\end{array}$ & $(25)$ \\
\hline $\begin{array}{l}\text { Lee } \text { et al, } \\
2010\end{array}$ & In vitro & PCR & $\begin{array}{l}\text { Cell culture } \\
\text { (human } \\
\text { keratinocytes- } \\
\text { foreskins) }\end{array}$ & GH & $\begin{array}{l}\text { GH enhances the local formation } \\
\text { of IGF-I, which activates fibroblast } \\
\text { proliferation and keratinocyte migration }\end{array}$ & (26) \\
\hline
\end{tabular}


been performed in animals, not humans. Currently, large burn wounds as well as chronic diabetic ulcers are challenging clinical issues that are poorly addressed. Given the apparently beneficial role of IGF-I in wound healing, it would be of great value to utilize the clinical effects of IGF-I in such patients. In addition, since the main concern in chronic, partially healed wounds is an inappropriately excessive inflammatory response that fails to resolve (43), the research findings included in this systematic review suggest that local IGF-I administration would be of benefit in chronic, difficult-to-heal wound patients.

In conclusion, IGF-I is a hormone with profound anabolic activities and an important role in wound anaplasias. The IGF-I-induced stimulation of wound healing has been demonstrated in several animal studies. The present systematic review reports a potentially promising, evidence-based practice favoring the use of IGF-I in addressing patients with large burn wounds, chronic diabetic ulcers and patients with impaired wound healing, as IGF-I has been found to positively influence important outcomes of the wound healing process. However, several issues regarding IGF-I administration in those patients remain to be specified, such as the route of recombinant IGF-I administration, the recommended dosage, as well as the indications for its clinical use. Hence, more consistent clinical trials are needed, focusing on the medical use of recombinant IGF-1 in patients whose healing process has been compromised.

\section{Acknowledgements}

Not applicable.

\section{Funding}

No funding was received.

\section{Availability of data and materials}

Not applicable.

\section{Authors' contributions}

ZG conceived the subject of the review. EK and DV performed the literature search. APa and $\mathrm{APh}$ analyzed and interpreted the data. ZG wrote the manuscript. GK and DM critically revised the manuscript. All the authors have read and approved the final version of this manuscript. Data sharing is not applicable.

\section{Ethics approval and consent to participate}

Not applicable.

\section{Patient consent for publication}

Not applicable.

\section{Competing interests}

The authors declare that they have no competing interests.

\section{References}

1. Clark RAF: Cutaneous tissue repair: Basic biologic considerations. I. J Am Acad Dermatol 13: 701-725, 1985.

2. Ksander GA: Exogenous growth factors in der- mal wound healing. Annu Rep Med Chem 24: 223-232, 1989.

3. Lynch SE, Colvin RB and Antoniades HN: Growth factors in wound healing. Single and synergistic effects on partial thickness porcine skin wounds. J Clin Invest 84: 640-646, 1989.

4. Wahl SM, Wong $\mathrm{H}$ and McCartney-Francis N: Role of growth factors in inflammation and repair. J Cell Biochem 40: 193-199, 1989.

5. Rinderknecht $\mathrm{E}$ and Humbel RE: The amino acid sequence of human insulin-like growth factor I and its structural homology with proinsulin. J Biol Chem 253: 2769-2776, 1978.

6. Jansen M, van Schaik FM, Ricker AT, Bullock B, Woods DE, Gabbay KH, Nussbaum AL, Sussenbach JS and Van den Brande JL: Sequence of cDNA encoding human insulin-like growth factor I precursor. Nature 306: 609-611, 1983.

7. Philippou A, Maridaki M, Pneumaticos S and Koutsilieris M: The complexity of the IGF1 gene splicing, posttranslational modification and bioactivity. Mol Med 20: 202-214, 2014.

8. Karalaki M, Fili S, Philippou A and Koutsilieris M: Muscle regeneration: Cellular and molecular events. In Vivo 23: 779-796, 2009.

9. Stavropoulou A,Halapas A, Sourla A,Philippou A,Papageorgiou E, Papalois A and Koutsilieris M: IGF-1 expression in infarcted myocardium and MGF E peptide actions in rat cardiomyocytes in vitro. Mol Med 15: 127-135, 2009.

10. Philippou A, Papageorgiou E, Bogdanis G, Halapas A, Sourla A, Maridaki M, Pissimissis $\mathrm{N}$ and Koutsilieris M: Expression of IGF-1 isoforms after exercise-induced muscle damage in humans: Characterization of the MGF E peptide actions in vitro. In Vivo 23: 567-575, 2009.

11. Thomas G C, Psarros C, Gekas A, Vandoros PG, Philippou A and Koutsilieris M: Alternative splicing of IGF1 gene as a potential factor in the pathogenesis of Peyronie's disease. In Vivo 30: 251-256, 2016.

12. Philippou A, Halapas A, Maridaki M and Koutsilieris M: Type I insulin-like growth factor receptor signaling in skeletal muscle regeneration and hypertrophy. J Musculoskelet Neuronal Interact 7: 208-218, 2007.

13. Bhora FY, Dunkin BJ, Batzri S, Aly HM, Bass BL, Sidawy AN and Harmon JW: Effect of growth factors on cell proliferation and epithelialization in human skin. J Surg Res 59: 236-244, 1995.

14. Kanje M, Skottner A, Sjöberg J and Lundborg G: Insulin-like growth factor I (IGF-I) stimulates regeneration of the rat sciatic nerve. Brain Res 486: 396-398, 1989.

15. Sjöberg J and Kanje M: Insulin-like growth factor (IGF-1) as a stimulator of regeneration in the freeze-injured rat sciatic nerve. Brain Res 485: 102-108, 1989.

16. LeRoith D: Clinical relevance of systemic and local IGF-I: Lessons from animal models. Pediatr Endocrinol Rev 5 (Suppl 2): 739-743, 2008.

17. Moher D, Liberati A, Tetzlaff J and Altman DG; PRISMA Group: Preferred reporting items for systematic reviews and meta-analyses: The PRISMA statement. PLoS Med 6: e1000097, 2009.

18. Vogt PM, Lehnhardt M, Wagner D, Jansen V, Krieg M and Steinau HU: Determination of endogenous growth factors in human wound fluid: Temporal presence and profiles of secretion. Plast Reconstr Surg 102: 117-123, 1998.

19. Wicke C, Wagner S, Trabold O, Müller J, Hunt TK, Ranke MB, Becker HD and Elmlinger MW: Age-dependency of insulin-like growth factors, insulin-like growth factor-binding proteins, and acid labile subunit in plasma and wounds of surgical patients. Wound Repair Regen 10: 360-365, 2002.

20. Tsuboi R, Sato C, Shi CM and Ogawa H: Stimulation of keratinocyte migration by growth factors. J Dermatol 19: 652-653, 1992.

21. Kratz G, Lake M and Gidlund M: Insulin like growth factor-1 and -2 and their role in the re-epithelialisation of wounds; interactions with insulin like growth factor binding protein type 1 . Scand J Plast Reconstr Surg Hand Surg 28: 107-112, 1994.

22. Haase I, Evans R, Pofahl R and Watt FM: Regulation of keratinocyte shape, migration and wound epithelialization by IGF-1- and EGF-dependent signalling pathways. J Cell Sci 116: 3227-3238, 2003. 
23. Lee YR, Oshita Y, Tsuboi R and Ogawa H: Combination of insulin-like growth factor (IGF)-I and IGF-binding protein-1 promotes fibroblast-embedded collagen gel contraction. Endocrinology 137: 5278-5283, 1996.

24. Kuroda K, Utani A, Hamasaki Y and Shinkai H: Up-regulation of putative hyaluronan synthase mRNA by basic fibroblast growth factor and insulin-like growth factor-1 in human skin fibroblasts. J Dermatol Sci 26: 156-160, 2001

25. Hyde C, Hollier B, Anderson A, Harkin D and Upton Z: Insulin-like growth factors (IGF) and IGF-binding proteins bound to vitronectin enhance keratinocyte protein synthesis and migration. J Invest Dermatol 122: 1198-1206, 2004.

26. Lee SW, Kim SH, Kim JY and Lee Y: The effect of growth hormone on fibroblast proliferation and keratinocyte migration. J Plast Reconstr Aesthet Surg 63: e364-e369, 2010.

27. Baker J, Liu JP, Robertson EJ and Efstratiadis A: Role of insulin-like growth factors in embryonic and postnatal growth. Cell 75: 73-82, 1993.

28. Daughaday WH and Rotwein P: Insulin-like growth factors I and II. Peptide, messenger ribonucleic acid and gene structures, serum, and tissue concentrations. Endocr Rev 10: 68-91, 1989.

29. D'Ercole AJ, Stiles AD and Underwood LE: Tissue concentrations of somatomedin C: Further evidence for multiple sites of synthesis and paracrine or autocrine mechanisms of action. Proc Natl Acad Sci USA 81: 935-939, 1984

30. Philippou A, Maridaki M, Halapas A and Koutsilieris M: The role of the insulin-like growth factor 1 (IGF-1) in skeletal muscle physiology. In Vivo 21: 45-54, 2007.

31. Philippou A and Barton ER: Optimizing IGF-I for skeletal muscle therapeutics. Growth Horm IGF Res 24: 157-163, 2014

32. Bikle DD, Tahimic C, Chang W, Wang Y, Philippou A and Barton ER: Role of IGF-I signaling in muscle bone interactions. Bone 80: 79-88, 2015

33. Ohlsson C, Mohan S, Sjogren K, Tivesten A, Isgaard J, Isaksson O, Jansson JO and Svensson J: The role of liver-derived insulin-like growth factor-I. Endocr Rev 30: 494-535, 2009.

34. Blakytny R and Jude E: The molecular biology of chronic wounds and delayed healing in diabetes. Diabet Med 23: 594-608, 2006.

35. Skottner A, Arrhenius-Nyberg V, Kanje M and Fryklund L: Anabolic and tissue repair functions of recombinant insulin-like growth factor I. Acta Paediatr Scand Suppl 367: 63-66, 1990.
36. Mueller RV, Hunt TK, Tokunaga A and Spencer EM: The effect of insulinlike growth factor I on wound healing variables and macrophages in rats. Arch Surg 129: 262-265, 1994.

37. Jeschke MG, Schubert T, Krickhahn M, Polykandriotis E, Klein D, Perez-Polo JR, Przkora R and Herndon DN: Interaction of exogenous liposomal insulin-like growth factor-I cDNA gene transfer with growth factors on collagen expression in acute wounds. Wound Repair Regen 13: 269-277, 2005.

38. Provenzano PP, Alejandro-Osorio AL, Grorud KW, Martinez DA, Vailas AC, Grindeland RE and Vanderby R Jr: Systemic administration of IGF-I enhances healing in collagenous extracellular matrices: evaluation of loaded and unloaded ligaments. BMC Physiol 7: 2, 2007.

39. Lu H, Huang D, Saederup N, Charo IF, Ransohoff RM and Zhou L: Macrophages recruited via CCR 2 produce insulin-like growth factor-1 to repair acute skeletal muscle injury. FASEB J 25 358-369, 2011.

40. Kluge A, Zimmermann R, Münkel B, Mohri M, Sack S, Schaper J and Schaper W: Insulin-like growth factor I is involved in inflammation linked angiogenic processes after microembolisation in porcine heart. Cardiovasc Res 29: 407-415, 1995.

41. Yamashita N, Tashimo H, Ishida H, Matsuo $Y$, Arai $H$, Nagase $H$, Adachi $\mathrm{T}$ and Ohta $\mathrm{K}$ : Role of insulin-like growth factor-I in allergen-induced airway inflammation and remodeling. Cell Immunol 235: 85-91, 2005.

42. Spies M, Nesic O, Barrow RE, Perez-Polo JR and Herndon DN: Liposomal IGF-1 gene transfer modulates pro- and anti-inflammatory cytokine mRNA expression in the burn wound. Gene Ther 8: 1409-1415, 2001.

43. Loots MA, Lamme EN, Zeegelaar J, Mekkes JR, Bos JD and Middelkoop E: Differences in cellular infiltrate and extracellular matrix of chronic diabetic and venous ulcers versus acute wounds. J Invest Dermatol 111: 850-857, 1998.

44. Barreca A, Voci A, Minuto F, de Marchis M, Cecchelli E, Fugassa E, Giordano G and Gallo G: Effect of epidermal growth factor on insulin-like growth factor-I (IGF-I) and IGF-binding protein synthesis by adult rat hepatocytes. Mol Cell Endocrinol 84: 119-126, 1992. 